\title{
コンクリートの断熱温度上昇試験装置に関する 性能試験方法について
}

\section{METHOD FOR EVALUATING PERFORMANCE OF TESTING APPARATUS FOR ADIABATIC TEMPERATURE RISE OF CONCRETE}

\author{
鈴木康範* ・原田修輔**・前川宏一***・辻幸和**** \\ By Yasunori SUZUKI, Shusuke HARADA, Koichi MAEKAWA and Yukikazu TSUJI
}

\begin{abstract}
There is no reliable method to evaluate performance of testing apparatus for adiabatic temperature rise of concrete.

This paper reports measurement of specimens of different size, measurement for a long term, repeated measurement and measurement discrepancy among testing apparatus of the same type.

Comparison is also made between the time-dependent temperature change in mass concrete and the experimental adiabatic temperature rise under the same concrete placing conditions.

The series of tests has revealed that not only achievement of adiabatic condition in testing apparatus, but also comparison with time-dependent temperature changes in mass concrete is necessary to evaluate performance of the testing apparatus.
\end{abstract}

Keywords : testing apparatus, performance, adiabatic temperature rise, FEM

\section{1. まえがき}

マスコンクリート構造物については，温度ひびわれの 発生の有無を予测し，有効な手段を講じる目的で，一般 に温度および温度応力の計算が行われている．この温度 解析においては, コンクリートの発熱量として, コンク リートの断熱温度上昇量が通常用いられている.

コンクリートの断熱温度上昇量を測定する装置は, 従 来より数多く考案, 試作され, 改良が重ねられてきたに もかかわらず，その性能が十分に検討されてきたとはい いがたい.たとえば， RC 示方書および JCI 指針の断熱 温度上昇量の標準值の根拠となった実験データは, 試験 方法および試験装置自体の相違により，かなりばらつい た值であったことが報告されている1). また，断熱温度 上昇試験装置そのものの性能試験方法についても不明な 点が多い.

本研究では，試作した断熱温度上昇試験装置について

* 正会員 住友セメント(株) 技術開発センター （テ274 船橋市豊富町 585）

** 正会員 工修 住友セメント(株) 技術開発センター (同上)

*** 正会員 工博 東京大学助教授 工学部土木工学科 ( ₹113 文京区本郷 7-3-1)

**** 正会員 工博 群馬大学教授 工学部建設工学科 ( ₹376 桐生市天神町 1-5-1)
行った装置自体の性能試験方法と，打ち込まれるコンク リートの諸条件を同一として実構造物あるいはそれに類 する大型試験体の温度履歴と断熱温度上昇量との比較を とりまとめて報告するものである.

\section{2. 既往の研究}

わが国におけるコンクリートの断熱温度上昇量に関す る研究は,約 30 年前から報告されている.しかしながら, 統一した試験方法がないために，各研究者および技術者 によって，採用したコンクリートの断熱温度上昇試験装 置はまちまちである ${ }^{2), 3)}$.

また, 試験装置の性能の確認方法も, 各研究者および 技術者によって異なっている，高野らは，燃研式断熱力 ロリーメーターを改良した一種の水循環式の試験装置を 考案しており, その性能を, 大型の断熱カロリーメーター による値と比較して確認している ${ }^{4)}$. 柳田らは，土研式 と呼ばれる一種の水循環式の試験装置を考案し, 供試体 の容器に一定温度の温水を入れて, その後 $3 \sim 4$ 日間の 試験装置の断熱状態を測定することにより，性能の確認 を行っている5). 塚山は，ダムコンクリート用の空気循 環式の試験装置を大型化し，試料の量を増加し，また制 御面での応答速度を速めることにより, その性能を高め た.そして, 発熱速度が速いコンクリートの断熱温度上 
昇量を新旧両装置で測定し, その改良効果を確認してい $ろ^{6)}$.

一方, マスコンクリート構造物における温度測定例が, 近年数多く発表されている．その中のいくつかの報告で は, 従来発表されているコンクリートの断熱温度上昇量 の試験結果は, 実構造物の温度測定值を大幅に下回ると の指摘がなされているマ

これまで用いられてきたコンクリートの断熱温度上昇 試験装置は, ダムコンクリートのように単位セメント量 が少なく，比較的断熱温度上昇量が少ないコンクリート を対象としてきた。しかしながら，今日， RC 構造物で 温度ひびわれが問題となっているものは，単位セメント 量が $300 \mathrm{~kg} / \mathrm{m}^{3}$ 程度以上といった比較的富配合であり, 発熱が急速なコンクリートの場合も多い。したがって, 統一した試験方法が確立されていない現状では, 打ち込 まれるコンクリートの配合条件等を同一とし，断熱状態 と考えられる大型の実構造物あるいはそれに類する大型 試験体で実測した温度履歴と試験装置で測定された断熱 温度上昇量とを比較して，コンクリートの断熱温度上昇 試験装置の性能を確認することも必要と思われる.

\section{3. 実験に用いた断熱温度上昇試験装置}

本研究では, 図一1 に示すコンクリートの断熱温度上 昇試験装置を用いた。本試験装置は，著者らが新たに考 案した試験装置であり，内径が $60 \mathrm{~cm}$ ，内高が $60 \mathrm{~cm}$ の 隔壁構造の循環経路を有する熱媒ジャケットを，断熱材 を設けずに供試体に密着させ, 供試体の中心温度に熱媒 ジャケット内の熱媒の温度を追随させて, 供試体を断熱 状態に保ち，コンクリートの断熱温度上昇量を測定する 形式のものである ${ }^{10), 11)}$. その際, 最大で $30^{\circ} \mathrm{C} / \mathrm{h}$ 程度を 想定した中心温度の急激な変化にも, ジャケット内の熱 媒の温度を追随させるため, 遅れ補正演算器を備え, $0.2^{\circ} \mathrm{C}$ 以内の精度で制御を可能にした。なお，供試体お よび熱媒の温度は，白金抵抗体（JIS 0.2 級）で検出し ている.

熱媒としては, 主に水を用いた。また，単位セメント 量が多くかつ打込み温度が高く，断熱温度上昇量の值が $100^{\circ} \mathrm{C}$ 以上の高温となる場合にも，コンクリートの断熱 温度上昇量か測定できるように，水のほかにもシリコン オイルを熱媒としたものも一部試作した。また，本試験 装置は，粗骨材の最大寸法に合わせて十分均一な試料が 得られるように，供試体の寸法を，直径が $30 \mathrm{~cm}$ で高 さが $30 \mathrm{~cm}$ ，および直径が $60 \mathrm{~cm}$ で高さが $60 \mathrm{~cm}$ の円柱 の 2 通りに，熱媒ジャケットごと交換ができるものとし た.

\section{4. 断熱温度上昇量に影響を及ぼす諸要因}

\section{（1）供試体の寸法の影䉕}

供試体の寸法が異なる場合の断熱温度上昇量を求めた ものが図一2である，実験に用いた配合は，表一1 中の $\mathrm{C} 1$ で, 単位セメント量が $350 \mathrm{~kg} / \mathrm{m}^{3}$ の場合である.こ の図より, 直径が $60 \mathrm{~cm}$ で, 高さが $60 \mathrm{~cm}$ の円柱供試 体は，直径が $30 \mathrm{~cm}$ で高さが $30 \mathrm{~cm}$ のものに比べて, それぞれの寸法で 2 倍, すなわち体積が 8 倍と大きく なっても，コンクリートの断熱温度上昇量は最大でも $0.5^{\circ} \mathrm{C}$ 程度大きい值を示すだけであった。

\section{（2）断熱状態の維持能力の確認ならびに試験結果の 再現性}

中庸熱ポルトランドセメントをベースとして，高炉ス ラグおよびフライアッシュを混合した 3 成分系のセメン トを用いた，表一1 に示す配合 C 2 のコンクリートにつ いて, 打込み温度を $20^{\circ} \mathrm{C}$ として, 試験装置の再現性を

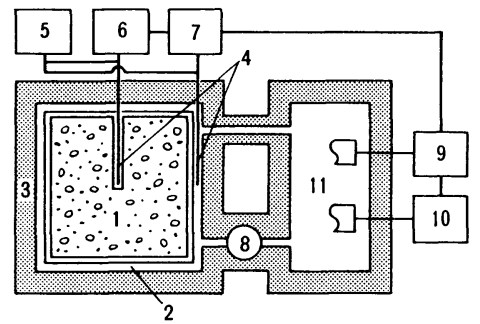

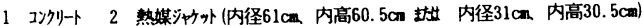
3 断熱材 (最小厚さ $10 \mathrm{~cm}$ ) 4 温度センサ- $\left(\right.$ 精度 $\left.\pm 0.2{ }^{\circ} \mathrm{C}\right) \quad 5$ 温度記録計 6 中心渴度指示計 (精度 $\left.\pm 0.2^{\circ} \mathrm{C}\right) 7$ 周井温度調節計 (精度 $\pm 0.2^{\circ} \mathrm{C}$ )

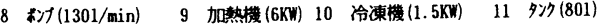

図一1断熱温度上昇試験装置の概要

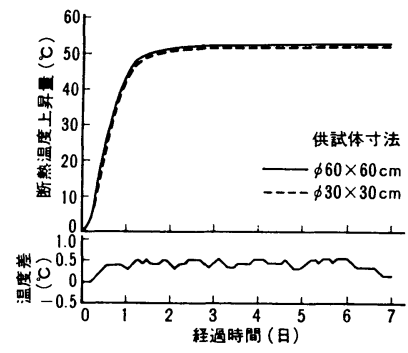

図一2 異なる供試体寸法の断熱温度上昇量

表一1 実験に用いたコンクリートの配合

\begin{tabular}{|c|c|c|c|c|c|c|c|c|c|}
\hline & \multirow{2}{*}{ 記号 } & \multirow{2}{*}{ 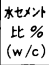 } & \multirow{2}{*}{$\begin{array}{l}\text { 細材 } \\
\text { 事\% } \\
(\mathrm{s} / \mathrm{a})\end{array}$} & \multicolumn{5}{|c|}{ 単位量 $\left(\mathrm{kg} / \mathrm{m}^{3}\right)$} & \multirow{2}{*}{$\begin{array}{l}\text { 打込み } \\
\text { 温 度 }\end{array}$} \\
\hline & & & & 水 & セxント & 紐骨材 & 粗龟材 & 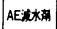 & \\
\hline コンクリート & C 1 & 42.3 & 40.4 & 148 & 350 & 736 & 1113 & 1.750 & 20.0 \\
\hline コンクリート & C 2 & 50.8 & 300 & 132 & & 726 & & & 20.0 \\
\hline コンクリート & C 3 & 50.0 & 40.6 & 150 & 300 & 760 & 1129 & 0.750 & 30.0 \\
\hline モルタル & M1 & 75.1 & - & 226 & 352 & 1525 & - & 0.106 & 26.0 \\
\hline コンクリート & C 4 & 74.5 & 42.1 & 158 & 212 & 812 & 1118 & 0.425 & 15.2 \\
\hline コンクリート & C 5 & 44.0 & 40.5 & 169 & 384 & 707 & 1078 & 0.96 & 26.0 \\
\hline
\end{tabular}


確認するために，繰り返し実験を行った．測定期間は 14 日とした。両実験に用いた材料は同一であり，約 1 か月の間隔をおいて実験を実施した.

図一3 に示す実験結果より，1回目と 2 回目の測定値 は最大で $0.9^{\circ} \mathrm{C}$ の差しか生じておらず，試験の再現性 は良好であるといえる.また, 1 回目および 2 回目とも， 打込み後 10 日以降は断熱温度上昇量がほとんど変化し ない，いわゆる断熱状態を示している，そして，その状 態が 4 日間ほど継続して維持されている.

\section{（3）同一タイプの試験装置間の測定誤差}

表一1 中の C 3 に示す配合のコンクリートを用いた場 合に, 同じ夕イプの 3 台の装置間によ゙の程度の誤差が生 じるかを示したのが図-4である. 3 台の試験装置のう ち 2 台は，熱媒として水を用いており，残りの 1 台は， シリコンオイルを用いている. また, 3 台の試験装置は, 約 1 年間ごとの間隔をおいて製作したものである.

熱媒として水を用いた 2 台の試験装置による測定値の 差は非常に小さく, 図一4にはそれらの大きい方の測定 值を示している，同一タイプの試験装置間では，水とシ リコンオイルという異なる熱媒を用いているにもかかわ らず，断熱温度上昇量の終局值が約 $50^{\circ} \mathrm{C}$ のンクリー トについて全測定期間を通じて生じた両者の誤差は, 最 大でも $1.5^{\circ} \mathrm{Cであった.}$

\section{5. 大型ブロック試験体の温度上昇量との比較}

試験装置により求めたコンクリートの断熱温度上昇量 と, 全面を厚さ $20 \mathrm{~cm}$ の発泡スチロールの断熱材で被 覆した $2 \mathrm{~m}$ 立方の大型ブロック試験体の中心部におけ る温度履歴との比較を行った。実験は，単位セメント量 が多く, かつ打込み温度が高いモル夕ルを用いて, セメ ントの水和発熱が急速な場合, および逆に単位セメント 量が少なく，かつ打込み温度が低いコンクリートを用い て，セメントの水和発熱が緩やかな場合の両方（表一1 の中の M 1 と C 4 ) について行った.

コンクリートの断熱温度上昇量と, 大型ブロック試験 体の中心温度の経時変化を併せて示したものが図一5で ある.コンクリートの断熱温度上昇量は, 打込み後 3 日 頃までは，断熱状態にほぼ近いと思われるブロック試験 体の中心部における温度の経時変化に対して $1.0^{\circ} \mathrm{C}$ 以 内の範囲に納まっており，温度上昇過程においてはほぼ 一致しているといえる.

温度上昇過程において, 試験装置による断熱温度上昇 量が大型ブロック試験体の中心温度にほぼ一致したから といって，ただちにその值が正確な断熱状態の值と認め ることはできない. なぜなら, 厚さ $20 \mathrm{~cm}$ の発泡スチ ロールの断熱材で被覆した 1 辺が $2 \mathrm{~m}$ のブロック試験 体中心部といえども，常に断熱材を通じて外部へ熱流が
生じており，その影響が打込み後 2 - 3 日を経過すると 徐々に顕著となり, 試験装置による断熱温度上昇量の終 局值の正確さが確認できないからである，そこで，試験 装置によるコンクリートの断熱温度上昇量の全般にわた る妥当性を検討するために, その值を用いて, 各大型ブ ロック試験体内の温度経時変化を FEM 解析により推 定し，その結果と実測値を比較した。

FEM 解析で用いた熱特性値は, 熱伝達率 $\alpha$ を除いて すべて実験により求めた。すなわち，モルタルまたはコ ンクリートの熱拡散率は, GLOVER 法により, 温水温 度を $60^{\circ} \mathrm{C}$, 冷水温度を $20^{\circ} \mathrm{C}$ ，また供試体の直径を 20 $\mathrm{cm}$ として求めた。比熱は，モルタルまたはコンクリ一 トの各構成材料の比熱を, それぞれ双子型恒温壁熱量計 を用いて求め, それぞれの配合割合より算定した。熱伝

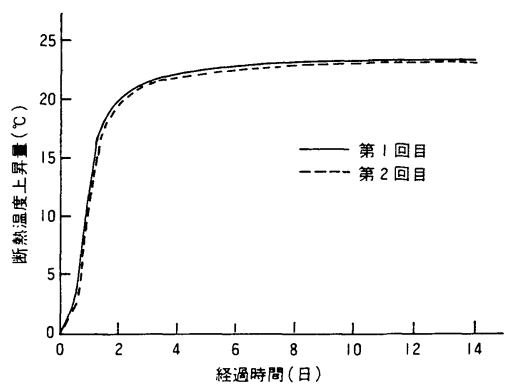

図一3＼cjkstart断熱状態の維持能力および試験結果の再現性

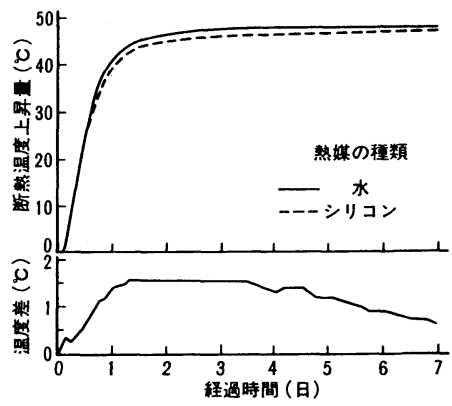

図一4 同一の試験装置の誤差（最大値と最小値）

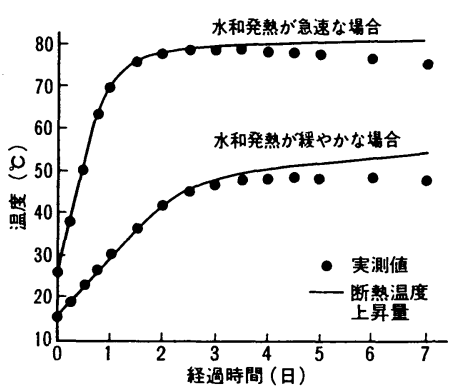

図一5 $2 \mathrm{~m}$ 立方ブロック試験体の中心温度の経時変化と断熱温 度上昇 
導率入は，上述の手法により実験的に求めた熱拡散率と 比熱，および密度を用いて，式（1）により算定した.

$$
\lambda=c \rho h^{2}
$$

ここで, $\lambda:$ 熱伝導率 $\left(\mathrm{kcal} / \mathrm{mh}^{\circ} \mathrm{C}\right)$

$$
\begin{array}{r}
c: \text { 比熱 }\left(\mathrm{kcal} / \mathrm{kg}^{\circ} \mathrm{C}\right) \\
h^{2}: \text { 熱拡散率 }\left(\mathrm{m}^{2} / \mathrm{h}\right)
\end{array}
$$$$
\rho: \text { 密度 }\left(\mathrm{kg} / \mathrm{m}^{3}\right)
$$

熱伝達率 $\alpha$ は, 水和発熱が急速な場合のブロック試 験体について，発熱がほぼ終了したと思われる打込み後 14 日から 28 日までの中心温度の推定值が，実測值の土 $0.5^{\circ} \mathrm{C}$ の範囲に収まるように, FEM 解析により $\alpha=$ $0.425 \mathrm{kcal} / \mathrm{m}^{2} \mathrm{~h}^{\circ} \mathrm{C}$ と定めた。 したがって，熱伝達率は コンクリートの発熱量とは無関係に, 実験的に求められ た他の熱特性値により算定されたのである．これらの熱 特性値は，表一2にまとめて示す.

温度解析の対象断面は, ブロック試験体の実測温度分 布を参考にして, 試験体断面の 4 分の 1 とした. 試験体 表面は, 熱伝達境界と仮定し，発泡スチロール断熱材は 要素とみなさず,上述のように等価熱伝達率に換算して, その影響を考慮した. 外気温は, 実測値を用いた。なお, 試験装置より得られたコンクリートの断熱温度上昇量を 時間の関数として近似式に当てはめると，そのための誤 差が少なからず生じるので，実測值の単位時間当たりの 温度上昇量に熱容量を乗じて，そのまま発熱量として用 いた。

$2 \mathrm{~m}$ 立方の大型ブロック試験体の中心部と表面部の温 度実測値と解析值の経時変化を示したのが図一6および 図一7である.なお，水和発熱が䋸やかな場合にも，熱 伝達率は, 水和発熱が急速な場合之同一の值を仮定した.

水和発熱が急速な場合には, 表面部の温度の解析値は, 実测值と比較して, 最大でも約 $1.6^{\circ} \mathrm{C} し か$ 誤差が生じ ていない.なお，表面部における実測値と解析値の誤差 は, 熱拡散率および比熱の実験誤差，さらにこれらの熱 特性值に温度依存性を考慮していないことも原因と思わ れる.

水和発熱が緩やかな場合にも，大型ブロック試験体の 中心部および表面部の温度の解析値は，実測值と良く一 致している. さらに，図一8に示す断面内の温度分布よ り, 温度の解析值は, 実測値と断面内の全域で良く一致 していることが認められる.

\section{6. 実構造物の温度上昇量との比較}

コンクリートの断熱温度上昇量と, 図一9 に示すよう に 1 回の施工区画が幅が $11 \mathrm{~m}$, 長さが $4.4 \mathrm{~m}$, 高さが $7 \mathrm{~m}$ とマッシブな防波堤コンクリートの温度履歴と比較 し，その值の適用性を検討する ${ }^{12)}$. なお，用いた配合は 表一1 中の C 5 であり，工事現場において打ち込まれた
コンクリートと同一の材料および配合で，しかも同一の 打込み温度により断熱温度上昇試験を行った。

コンクリートの断熱温度上昇量と，打込み後 2〜3 日 程度までのほぼ断熱状態とみなせる図一9中の測定点 No. 4 の温度経時変化を併せて示したものが図一10で ある.コンクリートの断熱温度上昇量は, 温度上昇過程 においては測定点 No. 4 の温度経時変化とほぼ一致し ているが，大型ブロック試験体の場合よりも誤差がやや

\begin{tabular}{|c|c|c|c|c|c|}
\hline \multirow{2}{*}{$\begin{array}{l}\text { 実験の } \\
\text { 種＼cjkstart別 }\end{array}$} & \multicolumn{4}{|c|}{ モルタルまたはコンクリートの熱特性値 } & \multirow{2}{*}{$\begin{array}{l}\text { 熱伝達事 } \\
(\mathrm{kcal} / \mathrm{m} 2 \mathrm{hr} t)\end{array}$} \\
\hline & $\begin{array}{l}\text { 慜伝道率 } \\
(k c a l / m h r c)\end{array}$ & $\begin{array}{c}\text { 比 熟 } \\
\text { (kcal/kgt) }\end{array}$ & $\begin{array}{l}\text { 密 度 } \\
\left(\mathrm{kg} / \mathrm{m}^{3}\right)\end{array}$ & $\begin{array}{r}\text { 熟拡散率 } \\
\left(10^{-3} \mathrm{~m}^{2} / \mathrm{hr}\right)\end{array}$ & \\
\hline 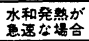 & 1.89 & 0.299 & 2145 & 2.95 & 0.425 \\
\hline 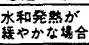 & 2.02 & 0.247 & 2300 & 3.55 & 0.425 \\
\hline
\end{tabular}
大きく, 最大で約 $2.2^{\circ} \mathrm{C}$ となった. 防波堤コンクリー

\section{表一2 大型ブロック試験体の熱特性值}

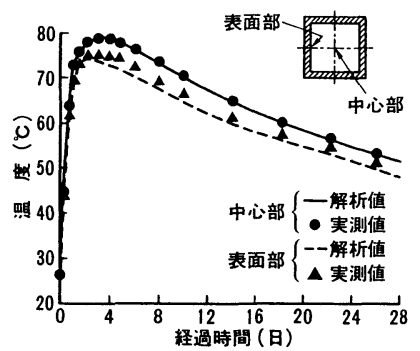

図一 $2 \mathrm{~m}$ 立方ブロック試験体の温度解析結果と実測估 （水和発熱が急速な場合）

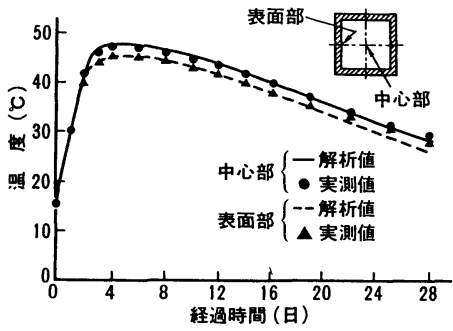

図一7 $2 \mathrm{~m}$ 立方ブロック試験体の温度解析結果と実測值 (水和発熱が緩やかな場合)

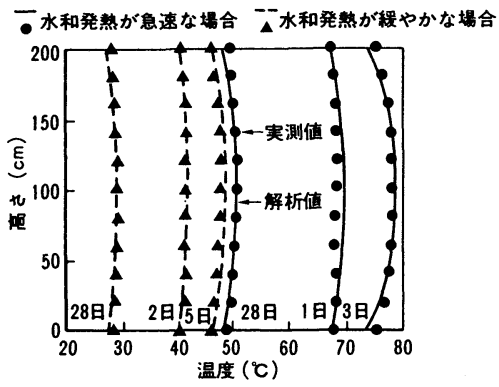

図一8 $2 \mathrm{~m}$ 立方ブロック試験体の温度分布 
トはトレミ一工法により打ち込まれる水中コンクリート であり，材料分離が少なからず生じることも誤差がやや 大きくなった原因と考えられる.

防波堤コンクリートの場合も大型ブロック試験体と同 様で，完全な断熱状態ではない，そこで，得られたコン クリートの断熱温度上昇量を用いて，防波堤コンクリー トの温度解析を FEM により行い，その断熱温度上昇 量の全般にわたる妥当性を検討した。

断熱温度上昇量以外のコンクリートの熱特性值は，既 往の文献を参考にして定めた ${ }^{13)}$ 。ただし，熱伝達率は，

5. の大型ブロック試験体の場合と同様に，防波堤下部 の断面中心部に位置する測定点 No. 4 の打込み後 14 日 から 28 日の温度の実測值の降下勾配に，推定値が士 $0.5^{\circ} \mathrm{C}$ の範囲内に収まるように, FEM 解析により求め た.これらの熱特性值は表一3に示すとおりである.

解析対象断面は, 底部の岩盤および既設の防波堤コン

(a) 防波堤の平面位置

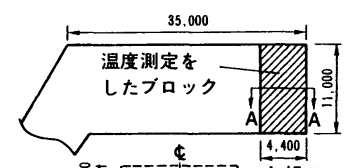

(b) 断面内の温度测定位羁

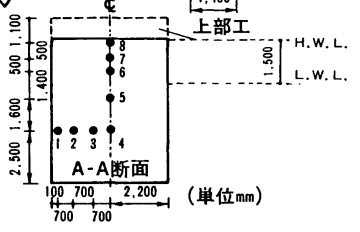

図一9 防波堤コンクリートの平面位置および断面内の温度測定 位置

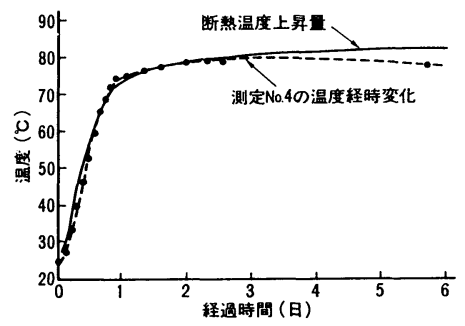

図一10 防波堤中心部の温度の経時変化と断熱温度上昇量

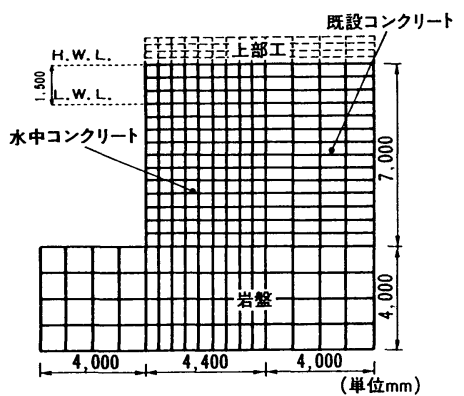

図一11 防波堤コンクリートの要素分割図
クリートを含むもので，図一11に示すような要素分割 を行った。空気または海水之接するコンクリート上面と 側面ならびに岩盤の上面で熱伝達境界とし, さらに岩盤 の上面より $4 \mathrm{~m}$ 下方の位置で固定温度境界とした.

陸上部で施工される上部工に近い測定点では，その打 込みの影響が温度の実測値に顕著に現われた。そこで, 解析では図一11に示す要素分割で, 水中コンクリート 部分の温度解析を上部工打継ぎ時まで行い，その時点の 各節点温度を求めた．次に，上部工を含む要素分割を新 たに行い，境界条件を修正した後，この值を初期温度と して与え, 再び解析を行った. なお, 外気温および海水 温度は, 実測值より日平均温度を求めて用いた。

防波堤コンクリートの温度の実測值と解析値との比較 を示したものが，図一12 および図一13である。これら の図より, 防波堤下部だけでなく, 上部工の打込みの影 響が現われる防波堤上部においても, 温度の実測値と解 析值は比較的良く一致していることが認められる.

\section{7. 結 論}

本研究では, まず試作した断熱温度上昇試験装置につ いての装置自体の性能を検討した。 その後打ち込まれる

表一3 防波堤コンクリートの温度解析に用いた熱特性値

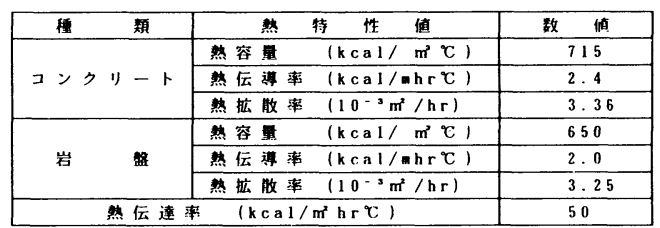

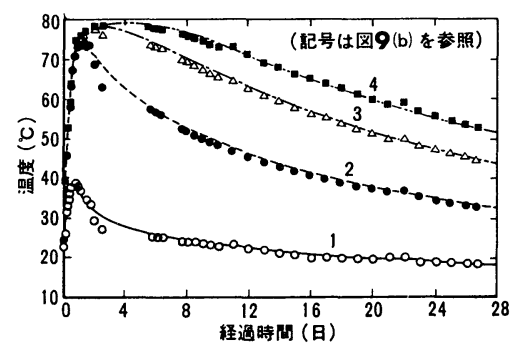

図一12 防波堤コンクリートの温度解析結果と実測値（その 1)

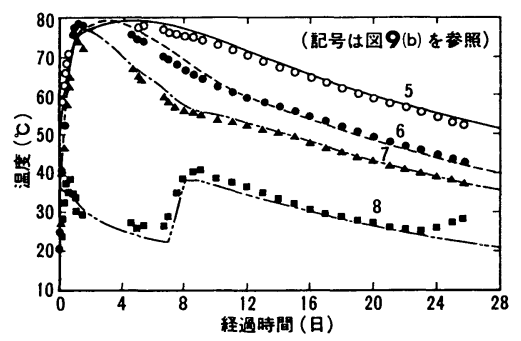

図一13防波堤コンクリートの温度解析結果と実測值（その 2) 
コンクリートの諸条件を同一として, 実構造物あるいは それに類する大型試験体の温度履歴と断熱温度上昇量之 の比較を行った．本研究の範囲からは，以下の知見が得 られた。

（1）試作した試験装置においては，供試体の寸法が 体積で 8 倍となっても，コンクリートの断熱温度上昇量 は最大でも $0.5^{\circ} \mathrm{C}$ 程度の差しか生じなかった。また， 断熱温度上昇量の増加がほとんど生じなくなる，打込み 後 11 日から 14 日の 4 日間においても断熱状態を維持で きること，同一材料および同一打込み温度で試験を繰り 返して実施した場合の試験結果には約 $0.9^{\circ} \mathrm{C}$ の温度差 しか生じないこと,さらに，同一タイプの試験装置間で

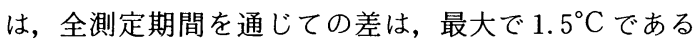
ことが認められた。

（2）打ち込まれるコンクリートの諸条件を同一とし た，実構造物あるいはそれに類する大型試験体の温度履 歴と試作した試験装置により測定された断熱温度上昇量 の比較では，コンクリートの発熱が急速な場合および緩 やかな場合も，断熱温度上昇量は断面内の中心部の温度 とほぼ一致した．ただし，断熱温度上昇量と断面内の中 心部の温度との誤差は，実構造物の場合の方が大型試験 体より大きくなった。

（3）コンクリートの断熱温度上昇試験装置の性能を 確認するのに，打ち込まれるコンクリートの諸条件を同 一とし，ほぼ断熱状態と考えられる大型試験体や，実構 造物の温度履歴との比較を行うことは上述のごとく有効 である．ただし，構造物の最小寸法によっては，中心部 でも断熱状態を保持することが困難なため, 断熱温度上 昇量の終局値の精度も併せて検討することが重要であ る。 その場合, FEM 解析による断面内各部の温度経時 変化の解析値之実測值の比較は, 有力な手法である.

謝辞：本研究を行うにあたり，東京大学 岡村 甫 教授には，有益なご助言，ご指導を頂きました。また， 住友セメント（株）横田紀男氏，佐藤利幸氏には，実験 の実施や論文作成にあたり，適切なご助言，ご支援を頂
きました．ここに深く感謝の意を表します.

\section{参 考 文 献}

1) 田辺忠顕：マスコンクリートの温度応力制御技術の現状, 土木学会論文集，第 372 号 $/ \mathrm{V}-5$, pp. $1 \sim 16,1986.8$.

2）平賀友晃・倉林 清：コンクリートの断熱温度上昇特性 に関する既往の研究成果について, マスコンクリートの 温度応力発生メカニズムに関するコロキウム論文集, pp. 1 6, 1982. 10.

3）小野 定：各種断熱温度上昇試験方法の比較，マスコン クリートの温度応力発生メカニズムに関するコロキウム 論文集, pp. 7 10, 1982.10.

4）高野俊介：打込み温度がマッスコンクリートの強度に及 ぼす影響の研究，土木学会論文集，第 26 号，pp. 5 6, 1955.5.

5）柳田 力・上野裕康：コンクリートの断熱温度上昇測定 装置について，セメント技術年報 XIV，pp. 317 319， 1965.

6）塚山隆一：マッシブな鉄筋コンクリートの温度上昇なら びに温度ひびわれに関する基礎研究, 学位論文 (東京大 学提出), pp. $75 \sim 96,1974$.

7）後藤貞雄：LNG 地下タンク底版コンクリートの温度ひび われ制御, マスコンクリートのひびわれ制御指針, pp. 191 200, 1986. 3.

8）吉田 隆・久保田信雄・中内博司：温水養生によるマス コンクリートの温度履歴, 温度応力に関する現場実験, 第 35 回土木学会年次学術講演会, pp. 165 166, 1980.

9）中山 誠・吉浪康行：ケーソン中埋コンクリート打設時 の温度上昇と温度応力, 第 35 回土木学会年次学術講演会, pp. 177 178, 1980.

10）鈴木康範・原田修輔・前川宏一・辻 幸和：温度解析に おける断熱温度上昇試験結果の適用性, 第 7 回コンクリー 卜工学年次講演会, pp. 25 28, 1985.

11）横田紀男・鈴木康範・原田修輔・佐藤利幸 : 断熱温度上 昇試験方法に関する一考察，セメント技術年報 39 , pp. 233〜236, 1985.5 .

12）横田紀男・鈴木康範・原田修輔・佐藤利幸：防波堤コン クリートの温度ひびわれに関する一考察，セメント技術 年報 40, pp. 395 398, 1986.5.

13）マスコンクリートの温度応力研究委員会報告書：日本コ ンクリート工学協会, pp. 17 23, 1985.11.

(1988. 4.19 - 受付) 